\title{
Mutations in a $\beta$-Tubulin Confer Resistance of Gibberella zeae to Benzimidazole Fungicides
}

\author{
Chang-Jun Chen, Jun-Jie Yu, Chao-Wei Bi, Yan-Nan Zhang, Jian-Qiang Xu, Jian-Xin Wang, and Ming-Guo Zhou
}

College of Plant Protection, Nanjing Agricultural University, Nanjing 210095, P.R. China.

Accepted for publication 28 July 2009.

\begin{abstract}
Chen, C.-J., Yu, J.-J., Bi, C.-W., Zhang, Y.-N., Xu, J.-Q., Wang, J.-X., and Zhou, M.-G. 2009. Mutations in a $\beta$-tubulin confer resistance of Gibberella zeae to benzimidazole fungicides. Phytopathology 99:14031411

Wheat head blight caused by Gibberella zeae (anamorph: Fusarium graminearum) is a threat to food safety in China because of mycotoxin contamination of the harvested grain, the frequent occurrence of the disease, and the failure of chemical control in some areas due to benzimidazole resistance in the pathogen population. The molecular resistance mechanism, however, of $G$. zeae to benzimidazole fungicides (especially carbendazim; active ingredient: methyl benzimidazol-2-yl carbamate $[\mathrm{MBC}])$ is poorly understood. DNA sequences of a $\beta$-tubulin gene $\left(\beta_{2} t u b\right)$ (GenBank access number FG06611.1) in G. zeae were

at codon 200. A highly resistant strain (MBC ${ }^{\mathrm{HR}}$ ) had two point mutations, one at codon 73, CAG (Gln) $\rightarrow$ CGG (Arg), and the other at codon 198, GAG (Glu) $\rightarrow$ CTG (Leu). To confirm that mutations in the $\beta_{2} t u b$ confer resistance to benzimidazole fungicides, the entire $\beta_{2} T u b$ locus was deleted from $\mathrm{MBC}^{\mathrm{MR}}$ and $\mathrm{MBC}^{\mathrm{HR}}$ strains of $G$. zeae. The resulting $\Delta \beta_{2} t u b$ mutants from both $\mathrm{MBC}^{\mathrm{MR}}$ and $\mathrm{MBC}^{\mathrm{HR}}$ strains grew normally on MBCfree potato dextrose agar medium and were supersensitive to $\mathrm{MBC}$. Complementation of the $\Delta \beta_{2} t u b$ mutants by transformation with a copy of the intact $\beta_{2}$ Tub locus from their parent strains exhibited less resistance than the original strains, and complementation of the $\Delta \beta_{2} t u b$ mutants by transformation with a copy of the intact $\beta_{2} T u b$ locus from sensitive strains restored $\mathrm{MBC}$ sensitivity. The results indicated that the mutations in the $\beta_{2} t u b$ gene conferred resistance of $G$. zeae to benzimidazole fungicides and this gene can be used as a genetic marker in G. zeae.
\end{abstract} analyzed. Mutations in $\beta_{2} t u b$ in moderately resistant strains $\left(\mathrm{MBC}^{\mathrm{MR}}\right)$ included TTT (Phe) $\rightarrow$ TAT (Tyr) at codon 167 or TTC (Phe) $\rightarrow$ TAC (Tyr)
Additional keywords: gene-deletion and -complementation mutants.
Benzimidazoles and thiophanate are a group of broad-spectrum systemic fungicides that interact with tubulin (11), especially $\beta$ tubulin. The repeated use of these fungicides, whose active ingredient or metabolite is generally methyl benzimidazol-2-yl carbamate (MBC or carbendazim), often selects for resistance, which is a major practical problem in the use of these fungicides. Benzimidazole resistance has developed in many plant-pathogenic fungi after the fungicides have been used for 2 or 3 years $(5,32)$. Mutations at Glu198Ala, Val, Gly, Phe200Tyr, and other codons in $\beta$-tubulin have been associated with resistance (1). Mutations in codons 198 and 200 are also encountered in veterinary medicine, where parasitic nematodes have become resistant to treatment with benzimidazole nematicides (19).

Gibberella zeae (Schwein.) Petch (anamorph: Fusarium graminearum) is a filamentous ascomycete that causes economically important diseases on a variety of cereal crops $(23,28)$. On wheat, G. zeae can cause seedling blight, root rot, and head blight (or scab) resulting in yield loss, as well as contamination of grain with trichothecene and estrogenic mycotoxins $(3,7)$.

In China, the first case of resistance to MBC in G. zeae was detected in 1992 in Zhejiang Province after these fungicides had been used widely for 20 years (35). Previous studies showed that a $\beta$-tubulin gene (FG09530.1) $\left(\beta_{l} t u b\right)$ in G. zeae had high amino acid identity with that of the MBC-resistant gene from other filamentous fungi but none of mutations at this locus were found relating to resistance to benzimidazole fungicides (7). A similar

Corresponding author: M.-G. Zhou; E-mail address: mgzhou@njau.edu.cn

doi:10.1094/PHYTO-99-12-1403

This article is in the public domain and not copyrightable. It may be freely reprinted with customary crediting of the source. The American Phytopathological Society, 2009 lack of mutations in the $\beta_{1}$-tubulin associated with benzimidazole resistance has been reported in G. pulicaris (15). Yuan et al. reported that a major gene in $G$. zeae confers benzimidazole resistance based on the results of crossing analysis (35). The tubulin gene family in $F$. graminearum has five members, including $\alpha_{2}$-tubulin (FG00639.1), $\alpha$-tubulin (FG00397.1), $\beta_{1}$-tubulin (FG09530.1), $\beta_{2}$-tubulin (FG06611.1) and the $\gamma$-tubulin gene (FG09993.1). The genes coding $\alpha_{2}$-tubulin (FG00639.1) (9), $\alpha$ tubulin (FG00397.1) (6), the $\gamma$-tubulin gene (8), and $\beta_{1}$-tubulin (FG09530.1) (7), however, do not confer benzimidazole resistance in G. zeae. Thus, the current research is aimed at examining whether the mutations in $\beta_{2} t u b$, the other known gene in the family, can confer resistance to benzimidazoles.

The objectives of this article were to (i) sequence the $\beta_{2} t u b$ from strains differing in MBC sensitivity to determine if mutations are present that may be correlated with differences in phenotype and (ii) confirm the identity of the resistant phenotypes by construction of gene-deletion and -complementation mutants.

\section{MATERIALS AND METHODS}

Fungicide, media, and pathogens. Potato dextrose agar (PDA) ( $20 \mathrm{~g}$ of dextrose, $15 \mathrm{~g}$ of agar, and infusion of $200 \mathrm{~g}$ of potato in 1 liter of distilled water) was used in routine in vitro assays for MBC sensitivity, and technical grade MBC (MBC, 93\% a.i.) was kindly provided by Dr. Si N-G (Shenyang, China). MBC was dissolved in $0.1 \mathrm{M} \mathrm{HCl}$ at $10 \mathrm{mg} / \mathrm{ml}$ as a stock solution and was added to autoclaved media after cooling to 45 to $50^{\circ} \mathrm{C}$. The $\mathrm{pH}$ was adjusted to 6.8 in all media using $\mathrm{HCl}$.

Fifteen MBC-sensitive $\left(\mathrm{MBC}^{\mathrm{S}}\right)$ strains of $G$. zeae previously characterized at the discriminating concentration of $\mathrm{MBC}$ at 1.4 $\mu \mathrm{g} / \mathrm{ml}$ (35), 16 strains moderately resistant to $\mathrm{MBC}\left(\mathrm{MBC}^{\mathrm{MR}}\right)$, and 1 strain highly resistant to $\mathrm{MBC}\left(\mathrm{MBC}^{\mathrm{HR}}\right)$ were collected from 
winter wheat in Zhejiang and Jiangsu Provinces. All strains tested were generated from single conidia dissected from contaminated heads (Table 1). To test the sensitivity of G. zeae to MBC, PDA was amended with $\mathrm{MBC}$ at $0,0.2,0.4,0.6,0.8,1.0$, and $1.2 \mu \mathrm{g}$ a.i./ml for sensitive strains or isolates or at $0,3.125,6.25,12.5$, 25,50 , and $100 \mu \mathrm{g}$ a.i./ml for resistant strains or isolates. A mycelial plug ( $5 \mathrm{~mm}$ in diameter) from the growing edge of a 5-dayold colony was transferred onto each plate amended with $\mathrm{MBC}$ as listed above. After incubation at $25^{\circ} \mathrm{C}$ for 5 days, the radial growth (colony diameter) was measured. A linear regression of the percent inhibition (relative to the $0 \mu \mathrm{g}$ a.i. control) versus the $\log _{10}$ transformation of each MBC concentration was obtained, and the effective concentration giving $50 \%$ inhibition $\left(\mathrm{EC}_{50}\right)$ was calculated. The minimum inhibitory concentration (MIC) was defined as that concentration resulting in $100 \%$ mycelial growth inhibition. Each treatment had four replicates and assays were performed twice. The significance of the two assays was determined by analysis of variance (ANOVA) with Fisher's protected least significant difference (PLSD) using Statview (SAS Institute, Cary, NC). Based on differences in MBC sensitivity, tested strains were divided into three phenotypes as follows: high $\mathrm{MBC}$ resistance, MIC > $100 \mu \mathrm{g} / \mathrm{ml}$; intermediate $\mathrm{MBC}$ resistance, $100 \mu \mathrm{g} / \mathrm{ml}$ $>$ MIC > $50 \mu \mathrm{g} / \mathrm{ml}$; MBC sensitive, $\mathrm{MIC}<1.4 \mu \mathrm{g} / \mathrm{ml}$ (35).

Cloning, sequencing, and analyses. For cloning the whole $\beta_{2}$ Tub locus, eight primer pairs $(30-31,32-33,34-35,36-37,38-$ $39,40-41,42-43$, and 44-45) (Table 2) were used to amplify products from genomic DNA of G. zeae. LA Taq DNA polymerase (TaKaRa, Dalian, China), a high-fidelity DNA polymerase, was used in all polymerase chain reaction (PCR) reactions except for reverse-transcriptase (RT)-PCR and the procedure of constructing the $\beta_{2} t u b$ deletion vector pMD-B2T. Genomic DNA was extracted from $\approx 1 \mathrm{~g}$ of freeze-dried mycelia of $G$. zeae strains which were grown in a potato dextrose broth (PDB) (20 g of dextrose and infusion of $200 \mathrm{~g}$ of potato in 1 liter of distilled water) at $25^{\circ} \mathrm{C}$ for 4 days. The DNA extraction method was adapted by a modified cetyltrimethylammonium bromide method (27). The genomic DNA was precipitated with $\approx 2.5$ volumes of ethanol and $1 / 10$ volume of $3 \mathrm{M}$ sodium acetate, washed twice with $70 \%$ ethanol, and dissolved in 50 to $100 \mu \mathrm{l}$ of Tris-EDTA buffer (10 mM Tris-HCl, 1 mM EDTA, pH 7.4). The PCR products were cloned into the pGEM-T Easy Vector (Promega Corp., Madison, WI). Escherichia coli strain DH5 $\alpha$ was used as the bacterial host for the propagation of constructs. Plasmid DNA was extracted with the Axyprep Plasmid Miniprep Kit (Axygen, China) following the manufacturer's instructions. DNA was sequenced by dideoxy chain-termination method (29) using the BigDye Terminator v3.1 Cycle Sequencing Kit (Applied Biosystems, Foster, CA) with the ABI PRISM 3730XL DNA Analyzer (Applied Biosystems). Three clones were sequenced for each isolate and both DNA strands were sequenced for each clone. Sequence analysis and multiple alignments were carried out with the Bioedit Sequence Alignment Editor software (14). Sequence homology of tubulin genes from $G$. zeae with other fungi was analyzed using the BLAST algorithm (2), and sequences from strains of $G$. zeae differing in MBC sensitivity were compared to determine mutations in the nucleotides associated with MBC resistance. The sequences were submitted to GenBank.

Nucleic acid manipulations. Total RNA was isolated from fresh mycelia ( $\approx 100 \mathrm{mg}$ ) using the TRIZOL Reagent (Invitrogen) according to the manufacturer's instructions. Total RNA was precipitated with 2-propanol, washed with $70 \%$ ethanol, dried, resuspended in $20 \mu \mathrm{l}$ of $\mathrm{RNase}-\mathrm{free} \mathrm{d}_{2} \mathrm{H}_{2} \mathrm{O}$, and finally treated with RNase-free DNaseI (TaKaRa). All nucleic acids were analyzed by electrophoresis on $0.7 \%$ agarose gels and spectrophotometrically (DU640: Beckman Coulter, Fullerton, CA).

Southern blotting was performed following the instructions of the DIG High Prime DNA Labeling and Detection Starter Kit I (Roche Applied Science, Germany). Briefly, the hybridization probes used in Southern analyses were labeled with digoxigenin (DIG). The EcoRV-digested genomic DNA of G. zeae was electrophoresed on 1\% agarose gels and capillary blotted onto positively charged nylon membranes (Roche Applied Science, Germany). After being hybridized at $48^{\circ} \mathrm{C}$ for $6 \mathrm{~h}$, the membranes were washed two times in $2 \times \mathrm{SSC}(1 \times \mathrm{SSC}$ is $0.15 \mathrm{M} \mathrm{NaCl}$ plus $0.015 \mathrm{M}$ sodium citrate) $-0.1 \%$ sodium dodecyl sulfate (SDS) at $20^{\circ} \mathrm{C}$ for $15 \mathrm{~min}$ and then two times in $0.5 \times \mathrm{SSC}-0.1 \% \mathrm{SDS}$ at $65^{\circ} \mathrm{C}$ for $15 \mathrm{~min}$.

Phylogenetic analysis. Amino acid sequences of $\beta$-tubulins from $G$. zeae and other plant pathogens were obtained from the public database GenBank. For phylogenetic analysis, the protein sequences were aligned with Clustal W (31) using the Blosum matrix and standard default parameters. The phylogenetic tree was constructed using MEGA software (18) with the neighborjoining method, excluding positions with gaps. The confidence of the branches was determined by bootstrap analysis in 1,000 samplings.

Construction of $\beta_{2} t u b$ deletion vector pMD-B2TK. This deletion vector was constructed in two steps. Vector pMD-B2T (Fig. 1A) was first constructed using a double-jointed PCR strategy (34) to amplify flanking sequences from the $\beta_{2} t u b$ gene.

TABLE 1 . Origin of strains or mutants and sensitivity of the strains to benzimidazole used in this study

\begin{tabular}{|c|c|c|c|}
\hline Resistant phenotype of strains ${ }^{a}$ & No. & Codes of strains & Origin \\
\hline $\mathrm{MBC}^{\mathrm{S}}$ & 15 & $\mathrm{ZF}-43, \mathrm{ZF}-32, \mathrm{ZF}-22,2021, \mathrm{~T} 17$ and $\mathrm{S} 1 \sim \mathrm{S} 10$ & $\begin{array}{l}\text { ZF-43, ZF-32, ZF-22, and } 2021 \text { were } \\
\text { separated from Zhejiang province of } \\
\text { China in 2000; S1-S10 from } \\
\text { Zhejiang in 2003; and T7 from } \\
\text { Jiangsu province of China in } 2001\end{array}$ \\
\hline $\mathrm{MBC}^{\mathrm{MR}}$ & 16 & ZF-52, ZF-54, SP-2, R1 R10, r2, NT-7 and t1 & $\begin{array}{l}\text { ZF-52, ZF-54, and SP-2 were } \\
\text { separated from Zhejiang in } 2000 \text {; } \\
\text { R1-R10 also from Zhejiang but in } \\
\text { 2003; and r2, NT-7, and t1 from } \\
\text { Jiangsu in } 2006\end{array}$ \\
\hline $\mathrm{MBC}^{\mathrm{HR}}$ & 1 & JT04 & From Jiangsu in 2000 \\
\hline$\beta_{2} T u b$-deletion mutants & 9 & $\begin{array}{l}\Delta \beta_{2} t u b-2021 \mathrm{D} 51 \Delta \beta_{2} t u b-2021 \mathrm{D} 81 \Delta \beta_{2} t u b-2021 \mathrm{D} 96, \Delta \beta_{2} t u b-\mathrm{R} 9 \mathrm{D} 4 \Delta \beta_{2} t u b- \\
\text { R9D32 } \Delta \beta_{2} t u b-\mathrm{R} 9 \mathrm{D} 49, \Delta \beta_{2} t u b-\mathrm{JT} 04 \mathrm{D} 47 \Delta \beta_{2} t u b-\mathrm{JT} 04 \mathrm{D} 144 \Delta \beta_{2} t u b-\mathrm{JT} 04 \mathrm{D} 151\end{array}$ & $\ldots$ \\
\hline$\beta_{2} T u b$-complementation mutants & 18 & $\begin{array}{l}\beta_{2} t u b-2021 \mathrm{D} 96-\mathrm{JT} 04 \mathrm{C} 2, \beta_{2} t u b-\mathrm{R} 9 \mathrm{D} 49-\mathrm{R} 9 \mathrm{C} 1, \beta_{2} t u b-\mathrm{JT} 04 \mathrm{D} 144 \mathrm{JT} 04 \mathrm{C} 4, \beta_{2} t u b- \\
\text { 2021D96-JT04C3, } \beta_{2} t u b-\mathrm{R} 9 \mathrm{D} 49-\mathrm{R} 9 \mathrm{C} 4, \beta_{2} t u b-\mathrm{JT} 04 \mathrm{D} 144 \mathrm{JT} 04 \mathrm{C} 6, \beta_{2} t u b- \\
\text { 2021D96-JT04C5, } \beta_{2} t u b-\mathrm{R} 9 \mathrm{D} 49-\mathrm{R} 9 \mathrm{C} 6, \beta_{2} t u b-\mathrm{JT} 04 \mathrm{D} 144 \mathrm{JT} 04 \mathrm{C} 7, \beta_{2} t u b- \\
\text { 2021D96-R9C1, } \beta_{2} t u b-\mathrm{R} 9 \mathrm{D} 49-2021 \mathrm{C} 1, \beta_{2} t u b-J T 04 \mathrm{D} 144-2021 \mathrm{C} 2, \beta_{2} t u b- \\
\text { 2021D96-R9C3, } \beta_{2} t u b-\mathrm{R} 9 \mathrm{D} 49-2021 \mathrm{C} 3, \beta_{2} t u b-J T 04 \mathrm{D} 144-2021 \mathrm{C} 5, \beta_{2} t u b- \\
\text { 2021D96-R9C8, } \beta_{2} t u b-\mathrm{R} 9 \mathrm{D} 49-2021 \mathrm{C} 5, \beta_{2} t u b-J T 04 \mathrm{D} 144-2021 \mathrm{C} 7\end{array}$ & $\ldots$ \\
\hline
\end{tabular}

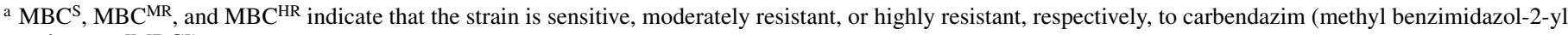
carbamate $[\mathrm{MBC}])$.
} 
Genomic DNA of G. zeae strain JT04 was used as a PCR template and sequences consisted of a $1-\mathrm{kb}$ upstream fragment (designated 1-up) and a 1.2-kb downstream fragment (designated 1.2-down). Amplification was done using the primer pairs 7-8 and 9-10, respectively. The two fragments with SmaI restriction sites were joined by double-jointed PCR using primers 1-2 and cloned into cloning vector pMD19T-Simple (TaKaRa). Second, a 1.4-kb PtrpC-hpt cassette containing the hygromycin phosphotransferase gene (hpt) under the control of a Aspergillus nidulans trpC gene promoter (PtrpC) was amplified from plasmid pKHt (26) with a polymerase that yields blunt-ended PCR products (Prime STAR HS DNA polymerase) (TaKaRa) and primers 11-12. The PCR product was cloned into the SmaI site of pMD-B2T to generate the deletion vector pMD-B2TK (Fig. 1B). The orientation of the inserted PtrpC-hpt cassette was confirmed by a three-primer combination, 1-2-6. The 3.6-kb 1-up:PtrpC-hpt:1.2-down fragment used to transform was amplified from pMD-B2TK using primers 1-2.

Transformation of the wild-type strain. Protoplasts were prepared by a modified method based on Maier et al. (23). Modifications were as follows: conidia of $G$. zeae strains harvested from 7-day-old mung bean broth cultures (3\% mung bean extract) were used to inoculate $100 \mathrm{ml}$ of yeast extract peptone dextrose (YEPD) (wt/vol: $1 \%$ peptone, $0.3 \%$ yeast extract, $2 \%$ glucose) at 1 to $5 \times 10^{6}$ conidia/ml. The inoculum was incubated at $28^{\circ} \mathrm{C}$ for 8 to $9 \mathrm{~h}$ at $200 \mathrm{rpm}$. Germlings were harvested by filtration on a $37-\mu \mathrm{m}$ nitrate filter, washed with $50 \mathrm{ml}$ of $0.7 \mathrm{M} \mathrm{NaCl}$, and suspended in $20 \mathrm{ml}$ of $0.7 \mathrm{M} \mathrm{NaCl}$ with a protoplasting enzyme mix (100 mg of lysing enzymes, $500 \mathrm{mg}$ of driselase, and $1 \mathrm{mg}$ of chitinase). The mixture was incubated at $28^{\circ} \mathrm{C}$ for 100 to $120 \mathrm{~min}$ at $80 \mathrm{rpm}$. Protoplasts were collected by centrifugation at $1,300 \times g$ for $5 \mathrm{~min}$, and then washed once in $10 \mathrm{ml}$ of ice-cold $0.7 \mathrm{M} \mathrm{NaCl}$ and twice in STC (0.8 M sorbitol; $50 \mathrm{mM}$ Tris- $\mathrm{HCl}, \mathrm{pH} \mathrm{8.0;} \mathrm{and}$ $50 \mathrm{mM} \mathrm{CaCl}_{2}$ ) buffer. The washed protoplasts were suspended in STC and stored on ice until transformation.

$\mathrm{MBC}^{\mathrm{S}}$ strain 2021, $\mathrm{MBC}^{\mathrm{MR}}$ strain R9, and $\mathrm{MBC}^{\mathrm{HR}}$ strain JT04 were transformed with the 3.6-kb 1-up:PtrpC-hpt:1.2-down fragment amplified from pNT-B2TK as described by Maier et al. (23). Putative transformants were transferred to PDA containing hygromycin $B$ at $150 \mu \mathrm{g} / \mathrm{ml}$, reisolated as single macroconidia, and maintained on PDA slants with hygromycin B.

Putative transformants $\left(n=192\right.$ for $\mathrm{MBC}^{\mathrm{S}}$ strain 2021, 181 for $\mathrm{MBC}^{\mathrm{MR}}$ strain R9, and 209 for $\mathrm{MBC}^{\mathrm{HR}}$ strain JT04) were obtained for two transformation experiments, including $\beta_{2} t u b$ deletion mutants and ectopic transformants.

PCR amplification and southern blot analysis of putative $\beta_{2} t u b$ deletion transformants. In all, 582 transformants of 2021, JT04, and R9 were analyzed to test for the presence of the wildtype $\beta_{2} t u b$ coding region and pMD-B2TK-specific sequence junctions. Primers 3-4 were used to detect the sequence of the $\beta_{2} t u b$ gene coding region (Fig. 1A to D). Two three-primer combinations, 16-26-27 and 6-28-29, were used to detect the two sequence junctions upstream and downstream of the $\beta_{2} t u b$ coding region, respectively. The second PCR screen used another two three-primer combinations to confirm the integration of pMDB2TK via homologous recombination at the $\beta_{2}$ Tub locus. The first set of three-primer combination consisted of oligonucleotides 15-16-27, which tested for integration of pMD-B2TK via recombination with DNA upstream of the $\beta_{2} T u b$ locus. The second set of three-primer combination consisted of oligonucleotides 5-6-28, which tested for integration of the vector via recombination with DNA downstream of the $\beta_{2} t u b$ coding region. Forty-two putative $\Delta \beta_{2} t u b$ mutants were identified for 2021, 32 for JT04, and 27 for R9.

Putative $\beta_{2} t u b$ deletion mutants (three derived from 2021, three from JT04, and three from R9) were selected for further analysis by Southern blot to confirm the homologous integration of the 1-up:PtrpC-hpt:1.2-down fragment. Probe 1 was prepared from a 0.3-kb fragment generated by using PCR primers 17-18 (Table 2) and corresponded to 1.2-down. Genomic DNA of each mutant was digested with EcoRV, separated by electrophoresis, blotted, and hybridized to probe 1 . The probe was expected to hybridize to a single $3.4-\mathrm{kb}$ band of DNA from the $\Delta \beta_{2} t u b$ mutant, a single 1.4-kb fragment from starting strains, and both fragments from transformants with an ectopic integration.

Construction of $\beta_{2} t u b$ complementation vector pAMDS$\beta_{2} \boldsymbol{T u b}$. To simultaneously complement $\Delta \beta_{2} t u b$ within the $G$. zeae

TABLE 2. Oligonucleotide primers used for plasmid construction, polymerase chain reaction analysis of transformants, and Southern hybridization blot analysis

\begin{tabular}{|c|c|}
\hline Primer no. & Sequence $\left(5^{\prime}-3^{\prime}\right)$ \\
\hline $1^{\mathrm{a}}$ & TTTGGGGTTTGCTTTTGGGGA \\
\hline 2 & GGAGCGAGGTGCTACTTGGCG \\
\hline $3^{\mathrm{b}}$ & CCACCGTCTCCAAGGAGCAC \\
\hline 4 & CGCAGATCCGAGTTGAGCTG \\
\hline 5 & GCAAGCTCCTCGACCTCATC \\
\hline 6 & TGCGACGCAATCGTCCGATC \\
\hline 7 & CTGATAAAGCGGTGAGATGAC \\
\hline 8 & CAATCTCACGCATCTTGACAG \\
\hline 9 & $\begin{array}{l}\text { CTGTCAAGATGCGTGAGATTGCCCGGGATACCAAGA } \\
\text { CGCCGACATCG }\end{array}$ \\
\hline 10 & TGACGATCCCAGCCGAACAC \\
\hline 11 & ACAGAAGATGATATTGAAGGAGC \\
\hline 12 & TACTCTATTCCTTTGCCCTCG \\
\hline 13 & ATATCTAGACTGCCAACAGCCACTATGTC \\
\hline 14 & ATACTCGAGGTCGCTACCCGTAACTCGTG \\
\hline 15 & TTCGGGTGGTTGGGATCAAG \\
\hline 16 & ATCAGGTCGGAGACGCTGTC \\
\hline $17^{\mathrm{c}}$ & AGTTACGGGTAGCGACAGAG \\
\hline 18 & TAGGTCTCGGACCTCGTCTG \\
\hline $19^{\mathrm{d}}$ & СТTACTGCCTCCACCAACTG \\
\hline 20 & TGACGTTGGAAGGAGCGAAG \\
\hline 21 & CTCTGACTGGTCGCAACATG \\
\hline 22 & AGTGGCGGACATGTCGAGAC \\
\hline $23^{\mathrm{e}}$ & CCTCGCGGATCTTGGACAG \\
\hline 24 & GGCAGACCATCTCTGGCGAG \\
\hline 25 & CGGACGACATCGAGAACTTG \\
\hline 26 & GACACCTAATAAGTGACCTC \\
\hline 27 & CAGAAGCTGGAACCGACTTG \\
\hline 28 & ACGACCAGTTCTCAGCCATG \\
\hline 29 & TCGTGCAGAGTCTGGTGCTC \\
\hline $30^{\mathrm{f}}$ & CTGCCAACAGCCACTATGT \\
\hline 31 & GTCAGCAAGCCACCCTAT \\
\hline 32 & ATTGGTGTAGTTGTTTCGTG \\
\hline 33 & ATCGCTGTATGTTCTACTGATT \\
\hline 34 & GATAAAGCGGTGAGATGA \\
\hline 35 & AACGGAAGGAAAGAAGAG \\
\hline 36 & AGCCTGAACTCACAACAA \\
\hline 37 & CATCAATACCGTGCTCCT \\
\hline 38 & GACCAGACCCAAAGACAC \\
\hline 39 & GAAGAAGCGTTCCCATAC \\
\hline 40 & CTGTTCTGGTCGATCTTG \\
\hline 41 & GGCTGGGAATTTCATTAG \\
\hline 42 & GAACCTTACAACGCCACTT \\
\hline 43 & TCCATCTCGTCCATACCC \\
\hline 44 & TCCGTCTGTTCCGTGCCT \\
\hline 45 & CTACCCGTAACTCGTGGG \\
\hline
\end{tabular}

a Primer pairs 1-2, 7-8, 9-10, and 11-12 were used in construction of pMDB2TK; Primer combination 1-2-6 was used to detect orientation of PtrpChpt cassette inserted into pMD-B2T.

b Primer pair 3-4 and combinations 16-26-27, 6-28-29, 15-16-27, and 5-6-28 were used to analysis of $\beta_{2}$-tubulin deletion mutants. Primer pair 3-4 was used to analysis of $\beta_{2}$-tubulin complementation mutants.

c Primer pair 17-18 was used to amplify the fragment to made probe 1 .

d Primer pairs 19-20, 21-22, and 24-25 were used to amplify the mitochondrial RNA transcript of elongation factor $1-\alpha-$ and the $\beta_{2^{-}}$and $\beta_{1^{-}}$ tubulin gene, respectively.

e Primer pair 3-23 was used to amplify the fragment to made probe 2 .

f Primer pairs 30-31, 32-33, 34-35, 36-37, 38-39, 40-41, 42-43, and 44-45 were used to amplify products (range from $2.2 \mathrm{~kb}$ upstream to $444 \mathrm{bp}$ downstream of $\beta_{2}$-tubulin coding region) from genomic DNA of Gibberella zeae strains. 
$\beta_{2}$ Tub locus, pAMDS- $\beta_{2}$ Tub-2021, pAMDS- $\beta_{2}$ Tub-R9, and pAMDS- $\beta_{2}$ Tub-JT04 were constructed. Fragments XbaI-XhoI $(4.3 \mathrm{~kb})$, containing the $\beta_{2} T u b$ locus digested from strains 2021 , $\mathrm{R} 9$, and JT04, were amplified by using primers 13-14 and ligated to the SpeI-SalI pAMDS4-1 (28) large fragment, respectively. pAMDS4-1 (provided by R. H. Proctor, Bioactive Agents Unit, National Center for Agricultural Utilization Research, United States Department of Agriculture-Agricultural Research Service, Peoria, IL), containing an Aspergillus nidulans acetamidase gene $(a m d S)$ under the control of the Cochliobolus heterostrophus Promoter I, facilitated the selection of transformants by their ability to grow on media in which acetamide is the sole source of nitrogen.

Transformation of the $\beta_{2} t u b$ deletion mutants. Protoplasts were prepared as described above. The transformation process $(23,28)$ was modified as follows: protoplasts were suspended at a concentration of 1 to $2 \times 10^{8} \mathrm{ml}^{-1}$ in four parts STC and one part
SPTC (e.g., STC with $40 \%$ polyethylene glycol 6000). Then, 5 to $20 \mu \mathrm{g}$ of pAMDS- $\beta_{2}$ Tub and $5 \mu \mathrm{l}$ of heparin $(5 \mathrm{mg} / \mathrm{ml}$ in STC) were added into $100 \mu \mathrm{l}$ of the protoplast suspension. After samples were mixed and incubated on ice for $30 \mathrm{~min}, 1 \mathrm{ml}$ of SPTC was mixed with the suspension and incubated at room temperature for $20 \mathrm{~min}$. The samples were diluted further with $4 \mathrm{ml}$ of STC; then, $600-\mu \mathrm{l}$ aliquots were mixed with $6.5 \mathrm{ml}$ of molten SL medium (28) containing $15 \mathrm{mM} \mathrm{CsCl}$ and $1 \%$ agarose and spread on SL medium. SL medium consisted of a previously described basal medium (10) plus $10 \mathrm{mM}$ acetamide (Sigma). After incubation at $28^{\circ} \mathrm{C}$ for 2 days, putative transformants were transferred to SL agarose slants and single-spore isolates were picked using inoculation needles. The pAMDS- $\beta_{2} T u b-2021$ was transformed into $\Delta \beta_{2} t u b$-R9D49 and $\Delta \beta_{2} t u b-J T 04 \mathrm{D} 144$; the pAMDS- $\beta_{2} T u b$-R9 was transformed into $\Delta \beta_{2} t u b$-R9D49 and $\Delta \beta_{2} t u b$-2021D96; and the pAMDS- $\beta_{2}$ Tub-JT04 was transformed into $\Delta \beta_{2}$ tub-JT04D144 and $\Delta \beta_{2} t u b-2021 \mathrm{D} 96$.
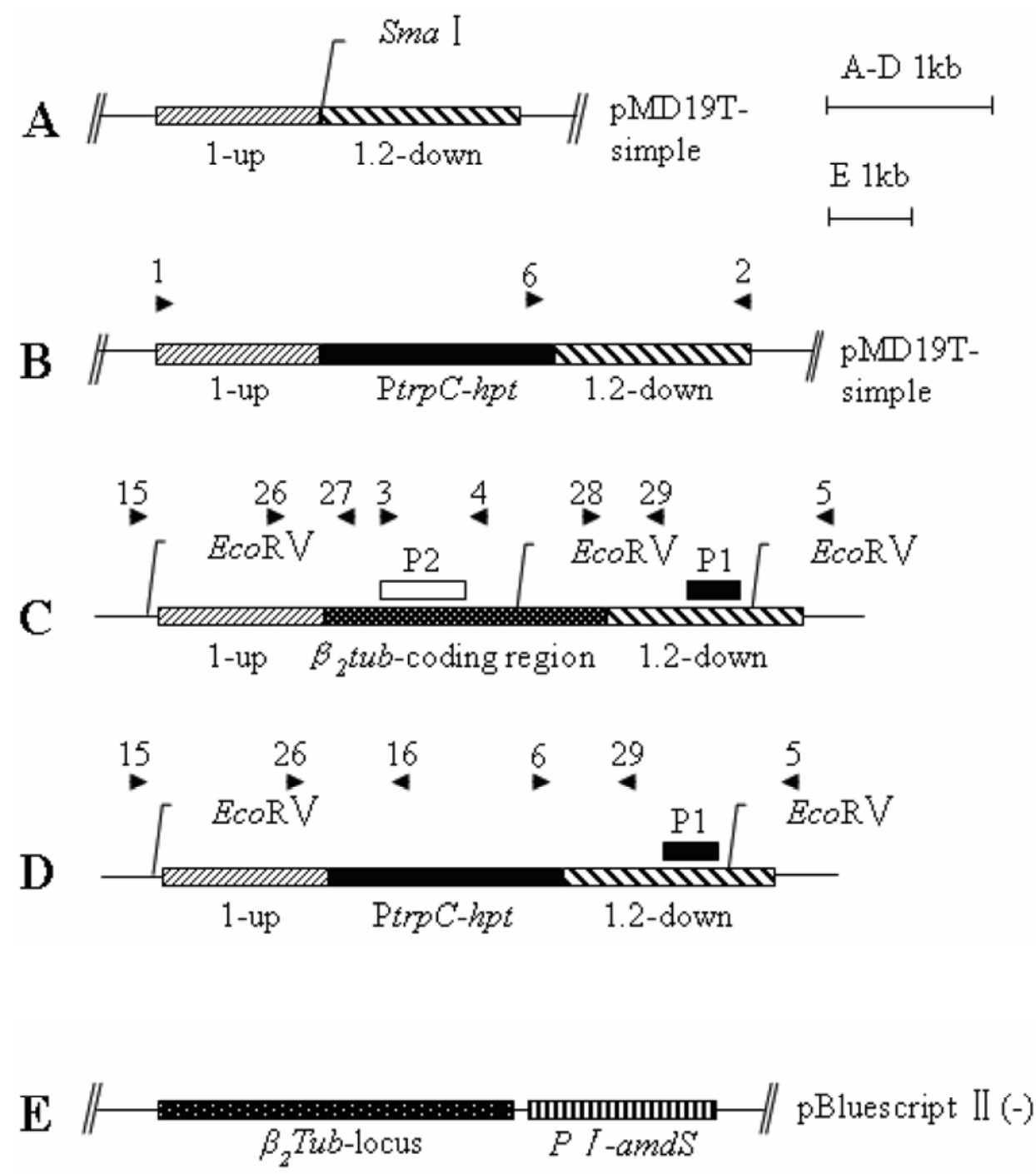

Fig. 1. Vectors constructed for this study. A, pMD-B2T. This fragment contained $1 \mathrm{~kb}$ upstream- (1-up) and $1.2 \mathrm{~kb}$ downstream (1.2-down) of $\beta_{2}$-tubulin gene $\left(\beta_{2} t u b\right)$ coding region, a SmaI restriction site between 1-up and 1.2-down, and pMD19T-simple vector backbone (TaKaRa, Dalian, China). B, $\beta_{2}$-Tubulin deletion vector pMD-B2TK. A blunt-ended polymerase chain reaction (PCR) fragment containing the hygromycin phosphotransferase gene (hpt) under the control of Aspergillus nidulans trpC gene promoter (PtrpC) was inserted into the SmaI site of pMD-B2T to generate pMD-B2TK. A three-primer (1-2-6) combination PCR was used to determine the orientation of 1-up:PtrpC-hpt:1.2-down. C, $\beta_{2}$-Tubulin locus $\left(\beta_{2}\right.$ Tub) of wild-type Gibberella zeae strain. Primer pairs 3-4, 26-27, and 28-29 were used to detect the presence of $\beta_{2}$ Tub. Probe1 (P1) and Probe2 (P2) labeled by digoxigenin (DIG) were used to hybridize to the 1.2 -down and $\beta_{2} t u b$ coding region, respectively. EcoRV was used to digest genomic DNA of the strains or mutants in Southern blot. D, $\beta_{2}$ tub Coding region of wild-type $G$. zeae strain replaced by PtrpC-hpt cassette. Primer pairs 16-26 and 6-29 were used to detect the presence of the 1-up:PtrpC-hpt:1.2-down cassette in the genomic DNA of transformants. Two primer pairs (15-16 and 5-6) were used to detect homologous recombination of 1-up:PtrpC-hpt:1.2-down cassette with $\beta_{2}$ Tub in G. zeae. $E c o R V$ was used to digest genomic DNA of the strains or mutants in the Southern blot. E, $\beta_{2}$ Tub-complementation vector pAMDS- $\beta_{2}$ Tub. A 4.3 -kb fragment of G. zeae $\beta_{2}$ Tub was inserted into the pAMDS4-1 to generate pAMDS- $\beta_{2}$ Tub. pAMDS4-1 consisted of a Promoter I-amdS cassette (Aspergillus nidulans acetamidase gene under the control of Cochliobolus heterostrophus promoter I) and the pBluescript II KS (-) (Stratagene, La Jalla, CA) backbone. 
PCR amplification and Southern blot analysis of putative $\beta_{2} t u b$-complementation transformants. This was done as above, except that the 0.8 -kb fragment which carries half of the $\beta_{2} t u b$ coding region (Fig. 1C) was amplified by primer $3-4$, and the 528-bp probe 2 , which was amplified from pAMDS- $\beta_{2} T u b-\mathrm{R} 9$ with primers $3-23$, was expected to hybridize to a single $2.1-\mathrm{kb}$ DNA fragment from wild-type strains and $\beta_{2} t u b$-complementation mutants.

RNA extraction and RT-PCR assay. Three strains differing in sensitivity to $\mathrm{MBC}\left(\mathrm{MBC}^{\mathrm{S}}\right.$ strain $2021, \mathrm{MBC}^{\mathrm{MR}}$ strain $\mathrm{R} 9$, and $\mathrm{MBC}^{\mathrm{HR}}$ strain JT04), three $\Delta \beta_{2} t u b$ mutants $\left(\Delta \beta_{2} t u b-2021 \mathrm{D} 96\right.$, $\Delta \beta_{2} t u b$-R9D49, and $\Delta \beta_{2} t u b$-JT04D144), and six $\beta_{2} t u b$-complementation mutants ( $\beta_{2} t u b$-R9D49-2021C3, $\beta_{2}$ tub-JT04D1442021C5, $\beta_{2} t u b-2021 \mathrm{D} 96-\mathrm{R} 9 \mathrm{C} 1, \beta_{2} t u b-2021 \mathrm{D} 96-\mathrm{JT} 04 \mathrm{C} 3, \beta_{2} t u b-$ R9D49-R9C1, and $\left.\beta_{2} t u b-J T 04 D 144-J T 04 C 4\right)$ were used to evaluate gene expression differences in $\beta_{1} t u b$ and $\beta_{2} t u b$. cDNA was produced from $0.8 \mu \mathrm{g}$ of total RNA from each strain using MMLV RT (Invitrogen) following the manufacturer's instructions and stored at $-20^{\circ} \mathrm{C}$. PCR was performed in a $25-\mu \mathrm{l}$ reaction mixture containing $2 \mu \mathrm{l}$ of RT reaction product, 1.25 units of Taq DNA polymerase (TaKaRa), $0.2 \mathrm{mM} \mathrm{dNTP}$, and $0.4 \mathrm{mM}$ each of forward and reverse primer in $1 \times$ PCR reaction buffer provided by the Taq enzyme supplier. A 253-bp mitochondrial (m)RNA transcript of the elongation factor $1-\alpha$ gene (EF-1- $\alpha$, a housekeeping gene) was amplified with primers 19-20 and used as a control. The 301-bp $\beta_{2} t u b$ - and 283-bp $\beta_{1} t u b$-mRNA transcripts were amplified with primer pairs 21-22 and 24-25, respectively. The reaction mixture was denatured at $94^{\circ} \mathrm{C}$ for $5 \mathrm{~min}$; amplified for 35 cycles of $30 \mathrm{~s}$ at $94^{\circ} \mathrm{C}$ for denaturation, $30 \mathrm{~s}$ at $60^{\circ} \mathrm{C}$ for annealing, and $30 \mathrm{~s}$ at $72^{\circ} \mathrm{C}$ for extension; followed by a single 10 -min extension at $72^{\circ} \mathrm{C}$.

Sensitivity of $\beta_{2} t u b$-deletion and -complementation mutants to MBC. The following strains and mutants were analyzed: 3 strains differing in MBC sensitivity $\left(\mathrm{MBC}^{\mathrm{S}} 2021, \mathrm{MBC}^{\mathrm{MR}} \mathrm{R} 9\right.$, and $\left.\mathrm{MBC}^{\mathrm{HR}} \mathrm{JT04}\right), 9 \beta_{2}$ tub-deletion mutants, and $18 \beta_{2} t u b-$ complementation mutants (Table 1). MBC was added to autoclaved PDA to produce a series of concentrations of $0,0.4,1.4$, 25 , and $100 \mu \mathrm{g}$ a.i./ml for mycelial growth assays and $0,1.25,2.5$, $5,10,20$, and $40 \mu \mathrm{g}$ a.i./ml for sensitivity assays with highly resistant strains; $0,0.018,0.036,0.072,0.14$, and $0.28 \mu \mathrm{g}$ a.i. $/ \mathrm{ml}$ for sensitivity assays with deletion mutants; and 0, 0.625, 1.25, $2.5,5,10$, and $20 \mu \mathrm{g}$ a.i./ml for sensitivity assays with complementation mutants. Each treatment had four replicates. The other experimental procedures were the same as those described above for the sensitivity assay.

\section{RESULTS}

Isolation and sequence analysis. The complete DNA sequences of a $\beta_{2} T u b$ locus (ranging from $2.2 \mathrm{~kb}$ upstream to $444 \mathrm{bp}$ downstream of the $\beta_{2} t u b$ coding region) from 32 strains of $G$. zeae were obtained following PCR amplification using four primer pairs (Table 2). There was an open reading frame (ORF) of $1,713 \mathrm{bp}$ interrupted by six introns. The positions of the introns were confirmed by comparison with the gene sequence from the PH-1 genomic database (http://www.broad.mit.edu/cgi-bin/annotation/fusarium/findfeatures). The ORF encodes a putative protein of 447 amino acids, with a calculated molecular weight of $50 \mathrm{kDa}, \mathrm{a} \mathrm{G}+\mathrm{C}$ content of $53 \%$, and an estimated isoelectric point of 4.5. There were 12 nucleotide differences, in total, between the $\beta_{2} t u b$ from all of the Chinese $\mathrm{MBC}^{\mathrm{S}}$ strains and the sequenced strain $\mathrm{PH}-1$.

Correlation between MBC-sensitive phenotypes and mutations in $\beta_{2} t \boldsymbol{t} \boldsymbol{b}$. Nucleotide changes occurred at positions 73 (CAG), 167,198 , and 200 in the predicted deduced amino acid sequence of the $\beta_{2} t u b$ gene from the Chinese strains of differing sensitivity to $\mathrm{MBC}$ (Table 3). $\mathrm{MBC}^{\mathrm{S}}$ strains had a glutamine at position 73 , a phenylalanine at position 167 (TTT), a glutamic acid at position 198 (GAG), and a phenylalanine at position 200 (TTC). Of the 16 $\mathrm{MBC}^{\mathrm{MR}}$ strains, 13 had a tyrosine at position 167 (TAT) and $3 \mathrm{had}$ a tyrosine at position 200 (TAC). MBC ${ }^{\mathrm{HR}}$ strain JT04 had an arginine at codon 73 (CGG) and a leucine at codon 198 (CTG). The GenBank accession numbers of $\beta_{2} t u b$ from different MBCsensitivity strains are FJ214662.1 to FJ214665.1.

Phylogenetic analysis. The analysis for $\beta$-tubulins from $G$. zeae and other selected plant pathogens was performed on the amino acid sequence. The alignment and cluster analysis were used to generate the phylogenetic tree. This first analysis grouped $\beta_{1} t u b$ of $G$. zeae in a branch together with MBC-resistant $\beta$ tubulins from some other plant pathogens, while $\beta_{2} t u b$ of $G$. zeae belonged to another branch with only one member.

Validation of the mutations correlated with resistance. Deletion of the $\beta_{2}$ tub. Hygromycin-resistant transformants were screened via PCR amplification for the presence of 1-up:PtrpC$h p t: 1.2$-down sequences and the $\beta_{2} T u b$ locus sequences of the three strains $\left(\mathrm{MBC}^{\mathrm{S}} 2021, \mathrm{MBC}^{\mathrm{MR}} \mathrm{R} 9\right.$, and $\mathrm{MBC}^{\mathrm{HR}}$ JT04) with two three-primer combinations (Fig. 1B to D; Tables 2 and 4). In all, 42 transformants of $\mathrm{MBC}^{\mathrm{S}} 2021,27$ transformants of $\mathrm{MBC}^{\mathrm{MR}}$ $\mathrm{R} 9$, and 32 transformants of $\mathrm{MBC}^{\mathrm{HR}} \mathrm{JT0} 4$ yielded 1-up:PtrpChpt:1.2-down-homologous recombination-specific amplicons (with primer pairs 16-26, 6-29,15-16, and 5-6) but no wild-type-specific amplicons (with primer pairs 3-4, 26-27, 28-29, 15-27, and 5-28). Some transformants had more complex banding patterns but these transformants were not characterized further. Nine of the transformants which were derived from 2021, R9, and JT04 were

TABLE 4. Predicted polymerase chain reaction (PCR) amplicon sizes for $\beta_{2^{-}}$ tubulin $\left(\beta_{2} t u b\right)$ deletion mutants of Gibberella zeae

\begin{tabular}{lcc}
\hline & \multicolumn{2}{c}{ Amplicon size $(\mathrm{bp})$ for $\beta_{2} t u b$ of $^{\mathrm{a}}$} \\
\cline { 2 - 3 } Primers & Wild-type strains & Deletion mutants \\
\hline $3-4$ & 804 & None \\
$15-16$ & None & 1,874 \\
$5-6$ & None & 1,440 \\
$16-26$ & None & 758 \\
$6-29$ & None & 586 \\
$26-27$ & 491 & None \\
$28-29$ & 559 & None \\
$15-27$ & 1,607 & None \\
$5-28$ & 1,413 & None
\end{tabular}

a Expected and observed sizes of PCR products amplified with the primer combinations indicated and DNA templates consisting of genomic DNA from carbendazim (methyl benzimidazol-2-yl carbamate [MBC])-sensitive strain 2021, moderately MBC-resistant strain R9, highly MBC-resistant strain JT04, and $\beta_{2} t u b$-deletion mutants.

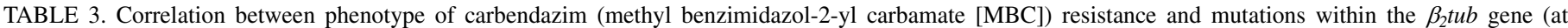
codons 73, 167, 198, and 200) in Gibberella zeae

\begin{tabular}{|c|c|c|c|c|c|c|}
\hline Phenotype $^{b}$ & No. & Names of strains & Codon 73 & Codon 167 & Codon 198 & Codon 200 \\
\hline $\mathrm{MBC}^{\mathrm{S}}$ & 15 & ZF-43, ZF-32, 2021, ZF-22, T17, S1-S10 & CAG(Gln) & TTT(Phe) & GAG(Glu) & TTC(Phe) \\
\hline $\mathrm{MBC}^{\mathrm{MR}}$ & 13 & $\mathrm{ZF}-52, \mathrm{ZF}-54, \mathrm{SP}-2, \mathrm{R} 1-\mathrm{R} 10$ & CAG(Gln) & $\mathrm{T} \mathrm{A} \mathrm{T}(\mathrm{Tyr})$ & GAG(Glu) & TTC(Phe) \\
\hline $\mathrm{MBC}^{\mathrm{MR}}$ & 3 & $\mathrm{NT}-7, \mathrm{r} 2, \mathrm{t} 1$ & CAG(Gln) & TTT(Phe) & GAG(Glu) & $\mathrm{TAC}$ (Tyr) \\
\hline $\mathrm{MBC}^{\mathrm{HR}}$ & 1 & JT04 & CGG(Arg) & TTT(Phe) & CTG(Leu) & TTC(Phe) \\
\hline
\end{tabular}

a Amino acid corresponding to each codon is presented in parentheses and nucleotides in boxes indicate the particular point mutation in the given codon.

${ }^{\mathrm{b}} \mathrm{MBC}^{\mathrm{S}}, \mathrm{MBC}^{\mathrm{MR}}$, and $\mathrm{MBC}^{\mathrm{HR}}$ indicate that the strain is sensitive, moderately resistant, or highly resistant, respectively, to carbendazim. 
randomly chosen and analyzed. Southern blots showed the predicted $\beta_{2} t u b$-deletion banding pattern (Fig. 2A).

Complementation of the $\beta_{2}$ Tub from $M B C^{R}$ strains into $\beta_{2}$ tub deletion mutants of $M B C^{R}$ strains. pAMDS- $\beta_{2}$ Tub-R9 and pAMDS- $\beta_{2}$ Tub-JT04 were transformed into $\beta_{2} t u b$-deletion mutants $\Delta \beta_{2} t u b$-R9D49 and $\Delta \beta_{2} t u b$-JT04D144. These two $\beta_{2} t u b$ deletion mutants were selected because they produced large numbers of conidia. In total, 14 acetamide-utilizing transformants were recovered from $\Delta \beta_{2} t u b$-R9D49 and 11 from $\Delta \beta_{2} t u b$ JT04D144. All of the transformants from $\Delta \beta_{2} t u b$-R9D49 and 8 of 11 transformants from $\Delta \beta_{2} t u b$-JT04D144 had the expected $0.8-\mathrm{kb}$ amplification product. Six of these restored $\beta_{2} t u b$ transformants analyzed by Southern blotting carried the $\beta_{2}$ Tub locus (Fig. 2B). Two bands were detected in the Southern blot analysis, of which the $2.1-\mathrm{kb}$ band was determined to be from the $\beta_{2}$ Tub locus (Fig. $2 \mathrm{~B}$ to $\mathrm{D})$.

Complementation of the $\beta_{2}$ Tub of $M B C^{R}$ strains into $\beta_{2}$ tub deletion mutants of $M B C^{S}$ strain. pAMDS- $\beta_{2}$ Tub-R9 was transformed into the $\beta_{2} t u b$-deletion mutant $\Delta \beta_{2} t u b-2021 \mathrm{D} 96$. The same procedure was done for pAMDS- $\beta_{2}$ Tub-JT04 for transformation into $\Delta \beta_{2} t u b$-2021D96. In all, 17 acetamide-utilizing transformants which transformed with pAMDS- $\beta_{2} T u b-\mathrm{R} 9$, and 14 acetamide-utilizing transformants with pAMDS- $\beta_{2}$ Tub-JT04 were analyzed by PCR with the primers 3-4 (Fig. 1). In total, 13 of 17 transformants using pAMDS- $\beta_{2}$ Tub-R9 and 13 of 14 transformants using pAMDS- $\beta_{2}$ Tub-JT04 contained the expected $0.8-\mathrm{kb}$ amplification product. Six transformants analyzed by Southern blotting contained the $\beta_{2}$ Tub locus (Fig. 2C).

Complementation of the $\beta_{2}$ Tub from $M B C^{S}$ strains into $\beta_{2}$ tub deletion mutants of $M B C^{R}$ strain. pAMDS- $\beta_{2} T u b-2021$ was transformed into $\Delta \beta_{2} t u b$-R9D 49 and $\Delta \beta_{2} t u b$-JT04D144, respectively. In all, 15 and 9 acetamide-utilizing transformants were recovered from $\Delta \beta_{2} t u b$-R9D49 and $\Delta \beta_{2} t u b$-JT04D144, respectively. In total, 13 of the 15 transformants using $\Delta \beta_{2}$ tub-R9D49 and 8 of the 9 transformants using $\Delta \beta_{2} t u b$-JT04D144 had the expected $0.8-\mathrm{kb}$ amplification product. All six of the $\beta_{2} t u b$ complementation mutants analyzed by Southern blotting contained the $\beta_{2} T u b$ locus (Fig. 2D).

Sensitivity of deletion- and complementation-mutants to MBC. Sensitivity to $\mathrm{MBC}\left(\mathrm{EC}_{50}\right)$ differed significantly among $\beta_{2} t u b$-deletion and -complementation mutants. The $9 \Delta \beta_{2} t u b \mathrm{mu}-$ tants and the $18 \beta_{2} t u b$-complementation mutants derived from $\mathrm{MBC}^{\mathrm{S}}$ strain 2021, $\mathrm{MBC}^{\mathrm{MR}}$ strain R9, and $\mathrm{MBC}^{\mathrm{HR}}$ strain JT04 were considered as four groups. There were significant differences in $\mathrm{EC}_{50}$ between these groups (Fig. 3; Table 5). EC $\mathrm{E}_{50}$ values of the $\Delta \beta_{2} t u b$ mutants (which were 0.08 to $0.1 \mu \mathrm{g} / \mathrm{ml}$ ) were much lower than that of $\mathrm{MBC}^{\mathrm{S}}$ strain $2021(0.6 \mu \mathrm{g} / \mathrm{ml})$. These $\Delta \beta_{2} t u b$ mutants were considered to be supersensitive to MBC. Comple-
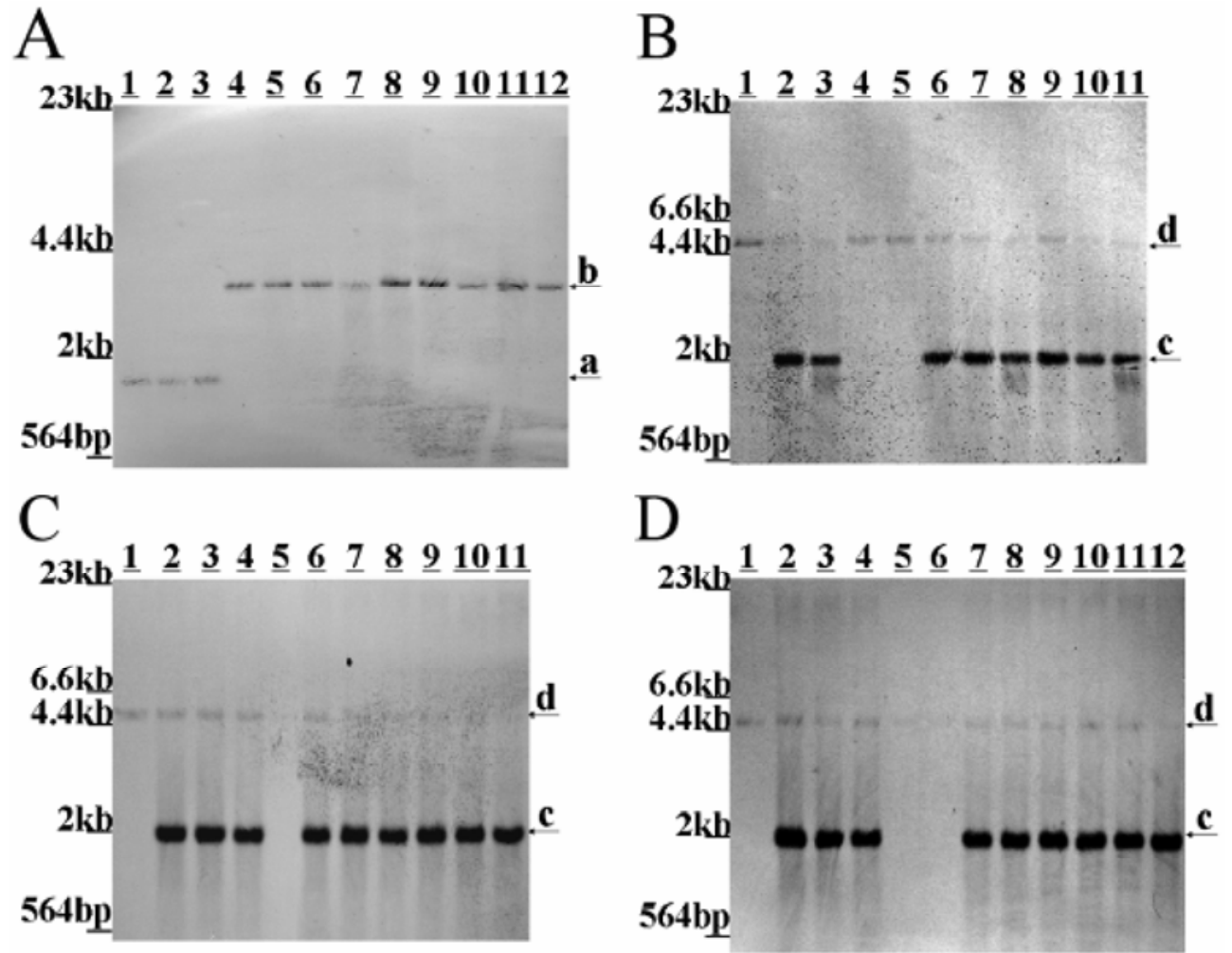

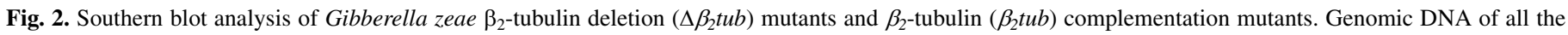

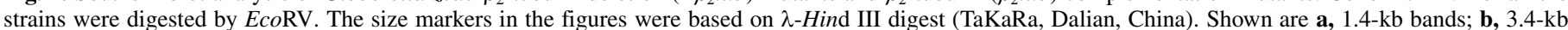

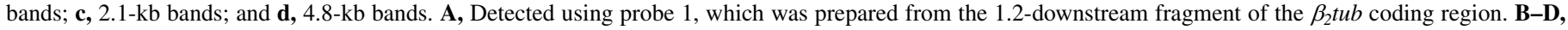

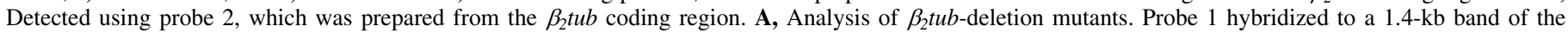

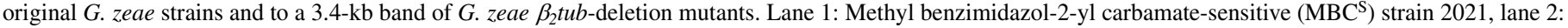

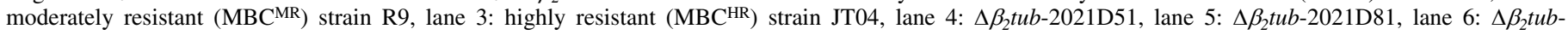

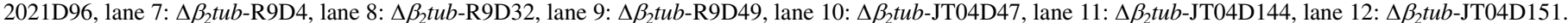

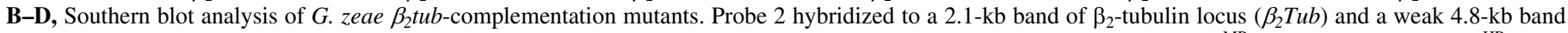

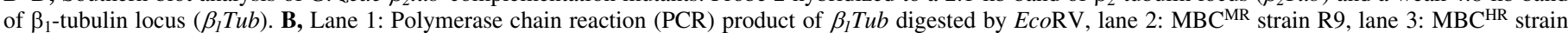

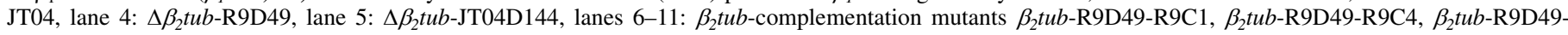

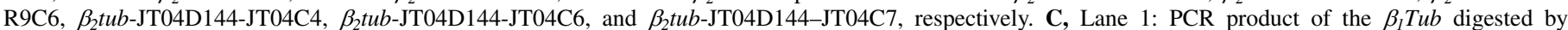

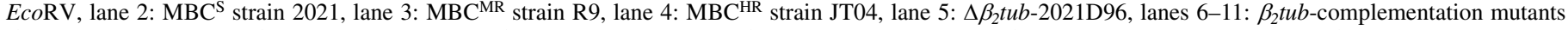

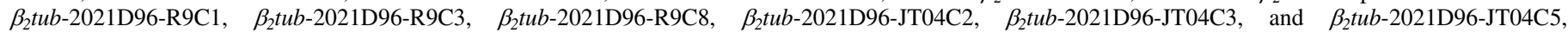

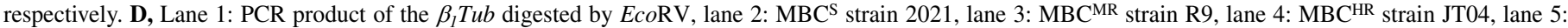

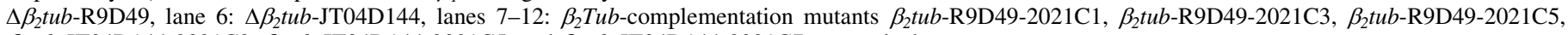
$\beta_{2} t u b$-JT04D144-2021C2, $\beta_{2}$ tub-JT04D144-2021C5, and $\beta_{2} t u b$-JT04D144-2021C7, respectively. 
mentation of the $\Delta \beta_{2} t u b$ mutants derived from $\mathrm{MBC}^{\mathrm{S}}$ strain 2021 with the $\beta_{2}$ Tub from $\mathrm{MBC}^{\mathrm{MR}} \mathrm{R} 9$ or $\mathrm{MBC}^{\mathrm{HR}}$ strain JT04 conferred the phenotype of moderate or high resistance, respectively, to $\mathrm{MBC}$. Complementation of $\Delta \beta_{2} t u b$ mutants derived from $\mathrm{MBC}^{\mathrm{HR}}$ strain JT04 and $\mathrm{MBC}^{\mathrm{MR}}$ strain R9 with the $\beta_{2}$ Tub locus from $\mathrm{MBC}^{\mathrm{S}} 2021$ restored the phenotype of sensitivity to MBC. Decreased sensitivity was observed in all complementation mutants, no matter what resistant strain was initially used to complement the $\beta_{2} T u b$ locus in the deletion mutants.

RT-PCR analysis of the expression of $\beta_{1} t u b$ and $\beta_{2} t u b$ genes in $\mathrm{MBC}^{\mathrm{S}}, \mathrm{MBC}^{\mathrm{MR}}$, and $\mathrm{MBC}^{\mathrm{HR}}$ strains of G. zeae and their $\beta_{2} t u b$-deletion and -complementation mutants. The RT-PCR fragments of $\beta_{1} t u b$ and $\beta_{2} t u b$ genes were detected in $\mathrm{MBC}^{\mathrm{S}}$ strain 2021 , MBC $^{\mathrm{MR}}$ strain R9, MBC ${ }^{\mathrm{HR}}$ strain JT04, and the six $\beta_{2} t u b$ complementation strains, whereas the RT-PCR fragments of $\beta_{2} t u b$ were not detected in the three $\beta_{2} t u b$-deletion mutants (Fig. 4).

\section{DISCUSSION}

In this study, the molecular basis for resistance to MBC in $G$. zeae is described. Based on transformation experiments with $G$. $z e a e$, we provide direct evidence that mutations at the $\beta_{2} t u b$ gene are responsible for resistance to benzimidazoles. In addition, this gene may be used as a genetic marker in G. zeae for biological research, similar to the genetic marker hpt in G. zeae.

The deduced amino acid sequences of the $\beta_{2} t u b$ and the $\beta_{l} t u b$ (another member of the tubulin gene family) in G. zeae were $76 \%$ identical (Fig. 5). $\beta_{1} t u b$ has higher similarity than $\beta_{2} t u b$ to the $\beta$ tubulin genes that have been shown to confer benzimidazole resistance in other plant pathogens $(7,15-17,30)$.

In the Southern blot analysis of wild-type strains and $\beta_{2} t u b$ complementation mutants (Fig. $2 \mathrm{~B}$ to $\mathrm{D}$ ), two bands were detected by probe 2 . The $2.1-\mathrm{kb}$ band is for $\beta_{2} t u b$ and another faint band of $\approx 4.8 \mathrm{~kb}$ was identified as a fragment of $\beta_{l} t u b$, which was $58 \%$ identical to probe 2 and spanned from 3,038 bp upstream to $104 \mathrm{bp}$ downstream of the $\beta_{l} t u b$-coding region (data not shown).

Mutations at different codons in the $\beta_{2} t u b$ resulted in altered amino acid sequences in the protein and different resistance to MBC. A single-point mutation (Phe167Tyr or Phe200Tyr) yielded moderate resistance to $\mathrm{MBC}$, and the double-point mutations (Gln73Arg and Glu198Leu) were detected in the $\mathrm{MBC}^{\mathrm{HR}}$ strain JT04. This $\mathrm{MBC}^{\mathrm{HR}}$ phenotype, however, was due to the mutation Glu198Leu rather than the mutation Gln73Arg and was confirmed by separately constructing the mutants with Gln73Arg and with Glu198Leu (data not shown). Of the three carbendazim-

TABLE 5. Carbendazim (methyl benzimidazol-2-yl carbamate [MBC]) sensitivity of $\beta_{2}$-tubulin $\left(\beta_{2} t u b\right)$-deletion and -complementation mutants of Gibberella zeae

\begin{tabular}{|c|c|}
\hline Strains or mutants ${ }^{\mathrm{a}}$ & $\mathrm{EC}_{50} / \mathrm{MIC}(\mu \mathrm{g} / \mathrm{ml})^{\mathrm{b}}$ \\
\hline $2021(\mathrm{~S})$ & $0.6 / 1.4$ \\
\hline$\Delta \beta_{2} t u b-2021 \mathrm{D} 51$ & $0.1 / 0.5$ \\
\hline$\Delta \beta_{2} t u b-2021 \mathrm{D} 81$ & $0.09 / 0.5$ \\
\hline$\Delta \beta_{2}$ tub-2021D96 & $0.1 / 0.5$ \\
\hline$\beta_{2} t u b-2021 \mathrm{D} 96-\mathrm{R} 9 \mathrm{C} 1$ & $6.5 / 60$ \\
\hline$\beta_{2} t u b-2021 \mathrm{D} 96-\mathrm{R} 9 \mathrm{C} 3$ & $6.8 / 60$ \\
\hline$\beta_{2}$ tub-2021D96-R9C8 & $7.0 / 60$ \\
\hline$\beta_{2} t u b-2021 \mathrm{D} 96-\mathrm{JT} 04 \mathrm{C} 2$ & $4.8 / 300$ \\
\hline$\beta_{2} t u b-2021 \mathrm{D} 96-\mathrm{JT} 04 \mathrm{C} 3$ & $4.6 / 300$ \\
\hline$\beta_{2} t u b-2021 \mathrm{D} 96-\mathrm{JT} 04 \mathrm{C} 5$ & $4.7 / 300$ \\
\hline R9 (MR) & $7.4 / 70$ \\
\hline$\Delta \beta_{2} t u b-\mathrm{R} 9 \mathrm{D} 4$ & $0.09 / 0.5$ \\
\hline$\Delta \beta_{2} t u b-\mathrm{R} 9 \mathrm{D} 32$ & $0.1 / 0.5$ \\
\hline$\Delta \beta_{2} t u b-\mathrm{R} 9 \mathrm{D} 49$ & $0.1 / 0.5$ \\
\hline$\beta_{2} t u b-\mathrm{R} 9 \mathrm{D} 49-\mathrm{R} 9 \mathrm{C} 1$ & $6.9 / 60$ \\
\hline$\beta_{2} t u b-\mathrm{R} 9 \mathrm{D} 49-\mathrm{R} 9 \mathrm{C} 4$ & $7.1 / 60$ \\
\hline$\beta_{2} t u b-\mathrm{R} 9 \mathrm{D} 49-\mathrm{R} 9 \mathrm{C} 6$ & $6.9 / 60$ \\
\hline$\beta_{2} t u b$-R9D49-2021C1 & $0.5 / 1.4$ \\
\hline$\beta_{2} t u b-\mathrm{R} 9 \mathrm{D} 49-2021 \mathrm{C} 3$ & $0.5 / 1.4$ \\
\hline$\beta_{2} t u b-\mathrm{R} 9 \mathrm{D} 49-2021 \mathrm{C} 5$ & $0.6 / 1.4$ \\
\hline JT04 (HR) & $6.9 / 400$ \\
\hline$\Delta \beta_{2} t u b-\mathrm{JT} 04 \mathrm{D} 47$ & $0.08 / 0.5$ \\
\hline$\Delta \beta_{2}$ tub-JT04D144 & $0.08 / 0.5$ \\
\hline$\Delta \beta_{2} t u b-\mathrm{JT} 04 \mathrm{D} 151$ & $0.1 / 0.5$ \\
\hline$\beta_{2} t u b-\mathrm{JT} 04 \mathrm{D} 144 \mathrm{JT} 04 \mathrm{C} 4$ & $4.4 / 300$ \\
\hline$\beta_{2} t u b-\mathrm{JT} 04 \mathrm{D} 144 \mathrm{JT} 04 \mathrm{C6}$ & $4.3 / 300$ \\
\hline$\beta_{2} t u b-\mathrm{JT} 04 \mathrm{D} 144 \mathrm{JT} 04 \mathrm{C} 7$ & $4.7 / 300$ \\
\hline$\beta_{2}$ tub-JT04D144-2021C2 & $0.5 / 1.4$ \\
\hline$\beta_{2} t u b-\mathrm{JT} 04 \mathrm{D} 144-2021 \mathrm{C} 5$ & $0.5 / 1.4$ \\
\hline$\beta_{2} t u b-\mathrm{JT} 04 \mathrm{D} 144-2021 \mathrm{C} 7$ & $0.5 / 1.4$ \\
\hline
\end{tabular}

${ }^{\mathrm{a}} \Delta \beta_{2} t u b$ - $\mathrm{D}^{*}$ and $\beta_{2} t u b-D^{*} C^{*}$ represent $\beta_{2} t u b$-deletion and -complementation mutants, respectively. S, MR, and HR indicate sensitive, moderately resistant, and highly resistant to $\mathrm{MBC}$, respectively.

${ }^{\mathrm{b}} \mathrm{EC}_{50}$ indicates $50 \%$ effective concentration, which is the fungicide concentration resulting in 50\% mycelial growth inhibition. The value of each $\mathrm{EC}_{50}$ is the mean of four replicates. Minimum inhibitory concentration (MIC) results in $100 \%$ mycelial growth inhibition.

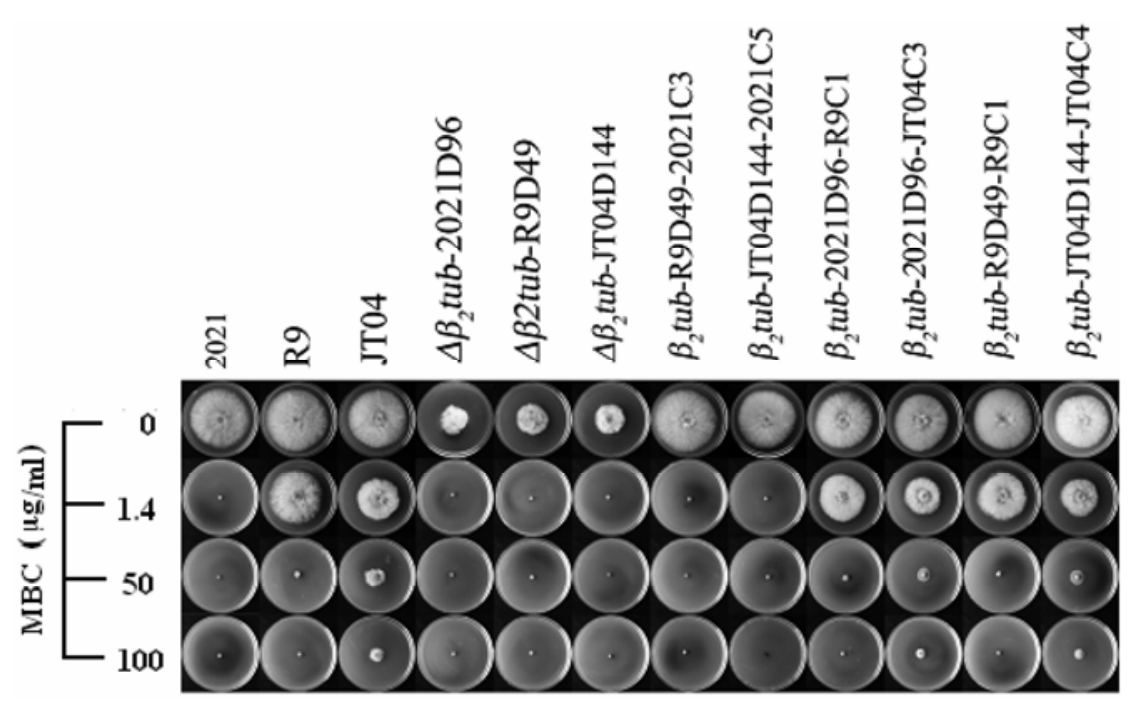

Fig. 3. Effects of carbendazim (methyl benzimidazol-2-yl carbamate $[\mathrm{MBC}]$ ) on mycelial linear growth of Gibberella zeae wild-type strains (2021, R9, and JT04) and $\beta_{2}$-tubulin $\left(\beta_{2} t u b\right)$-deletion and -complementation mutants on potato dextrose agar (PDA). The mycelial plugs ( $5 \mathrm{~mm}$ in diameter) taken from the edge of a 3 day-old colony of strains or mutants were grown at $25^{\circ} \mathrm{C}$ for 3 days on the PDA plates, which were amended with MBC at $0,1.4,50$, or $100 \mu \mathrm{g}$ a.i./ml. From left to right, lane 1: MBC-sensitive strain 2021; lane 2: MBC moderately resistant strain R9; lane 3: MBC highly resistant strain JT04; lanes 4-6: $\beta_{2}$ tub-deletion mutants $\Delta \beta_{2} t u b-2021 \mathrm{D} 96, \Delta \beta_{2} t u b$-R9D49, and $\Delta \beta_{2} t u b$-JT04D144, respectively; lanes 7-12: $\beta_{2} t u b$-complementation mutants $\beta_{2} t u b$-R9D49-2021C3, $\beta_{2} t u b$ JT04D144-2021C5, $\beta_{2}$ tub-2021D96-R9C1, $\beta_{2} t u b-2021 \mathrm{D} 96-\mathrm{JT} 04 \mathrm{C} 3, \beta_{2} t u b-\mathrm{R} 9 \mathrm{D} 49-\mathrm{R} 9 \mathrm{C} 1$, and $\beta_{2} t u b-\mathrm{JT} 04 \mathrm{D} 144-\mathrm{JT} 04 \mathrm{C} 4$, respectively. 
sensitive phenotypes found $\left(\mathrm{MBC}^{\mathrm{S}}, \mathrm{MBC}^{\mathrm{MR}}\right.$, and $\left.\mathrm{MBC}^{\mathrm{HR}}\right)$, the $\mathrm{MBC}^{\mathrm{HR}}$ phenotype took up $<1 \%$ of the $>10,000$ carbendazimresistant and -sensitive isolates tested in the laboratory, while the $\mathrm{MBC}^{\mathrm{MR}}$ phenotype accounted for $>99 \%$ of the selected resistant population. Of $>100 \mathrm{MBC}^{\mathrm{MR}}$ isolates sequenced (only some of isolates and strains are shown in Table 3), those with the mutation Phe167Tyr accounted for $>90 \%$ and isolates with the mutation Phe200Tyr accounted for $<10 \%$. Overall, $<10 \mathrm{MBC}^{\mathrm{HR}}$ isolates were detected from the nearly 2,000 MBC-resistant isolates collected (data not shown).

The mechanism of resistance to benzimidazole fungicides in $G$. zeae is different from that in other plant-pathogenic fungi that have been characterized. There are two main differences between them, as follows. First, in G. zeae, the substitution of Glu198Leu at $\beta_{2} t u b$ was unique, conferring a high resistance to MBC, ditho- fencarb (DFC), and methyl N-(3,5-dichorophenyl) carbamate (MDPC). This substitution is distinctly different from the Glu198Gln in the same gene, conferring resistance of the $F$. graminearum complex to benzimidazole (33). In other plant pathogens, however, five different substitutions at the same codon are found as follows. (i) The substitution of Glu198Ala in Botrytis cinerea (20), Helminthosporium solani (25), Monilinia fructicola (22), Penicillium expansum (17), Tepesia acuformis (1), T. yalhundae (1), and Venturia inaequalis (17) confers high resistance to carbendazim as well as insusceptibility to MDPC and DFC. (ii) The substitution of Glu198Gln in H. solani (25), T. acuformis (1), and $T$. yalhundae (1) confers low resistance to carbendazim and insusceptibility to MDPC as well as susceptibility to DFC. (iii) The substitution of Glu198Gly in V. inaequalis (17), T. acuformis (1), and T. yalhundae (1) confers moderate resistance to car-

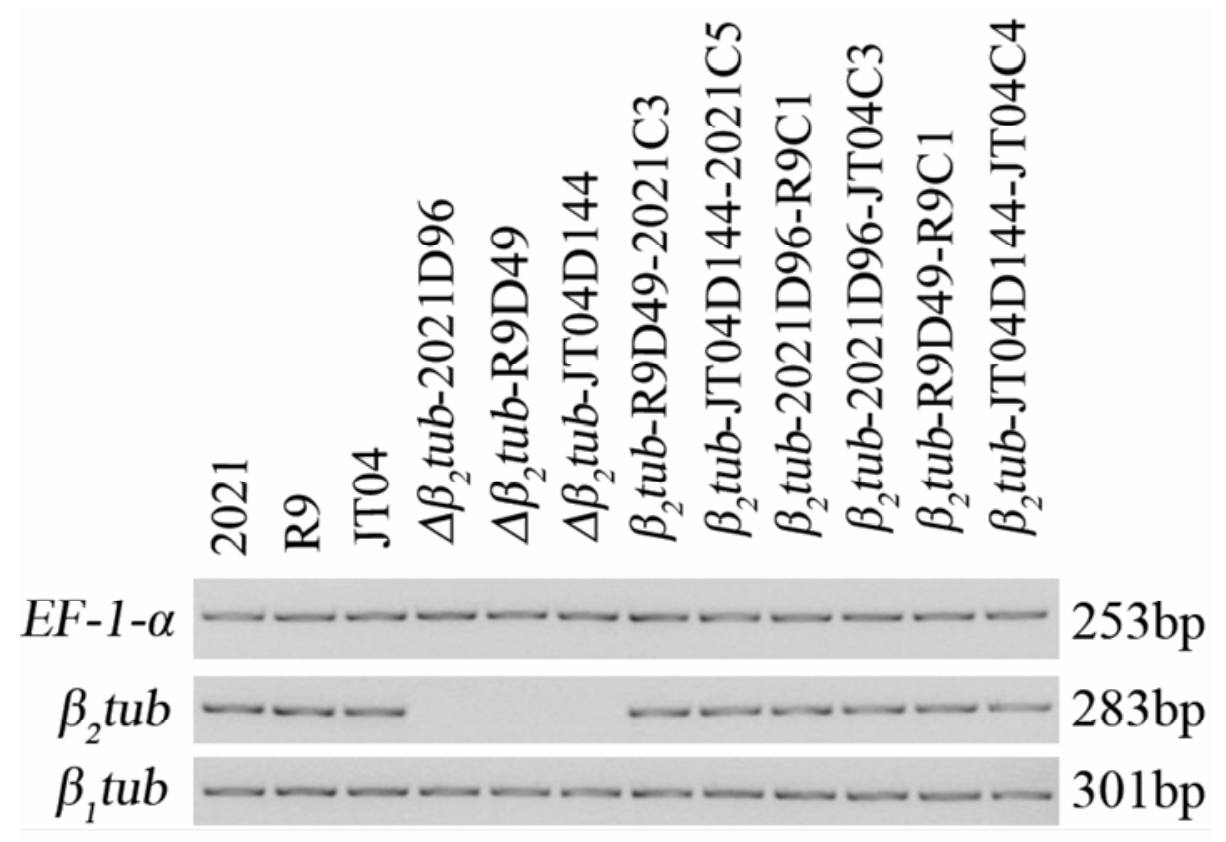

Fig. 4. Reverse transcriptase polymerase chain reaction (RT-PCR) fragments of $\beta_{1}$-tubulin $\left(\beta_{1} t u b\right)$ and $\beta_{2}$-tubulin $\left(\beta_{2} t u b\right)$ genes in methyl benzimidazol-2-yl carbamate-sensitive $\left(\mathrm{MBC}^{\mathrm{S}}\right)$ strain 2021, moderately resistant (MBC ${ }^{\mathrm{MR}}$ ) strain R9, highly resistant (MBC $\left.{ }^{\mathrm{HR}}\right)$ strain JT04, and $\beta_{2}$ tub-deletion and -complementary mutants derived from R9 and JT04 by RT-PCR. Elongation factor 1- $\alpha$ gene $(E F-1-\alpha)$, a housekeeping gene, was employed as a control. RT-PCR was performed with total RNA extracted from the strains or mutants. From left to right, lane 1: $\mathrm{MBC}^{\mathrm{S}}$ strain 2021; lane 2: MBC ${ }^{\mathrm{MR}}$ strain R9; lane 3: MBC ${ }^{\mathrm{HR}}$ strain JT04; lanes 46: $\beta_{2} t u b$-deletion mutants $\Delta \beta_{2}$ tub-2021D96, $\Delta \beta_{2}$ tub-R9D49, and $\Delta \beta_{2} t u b$-JT04D144, respectively; lanes 7-12: $\beta_{2} t u b$-complementation mutants $\beta_{2} t u b$-R9D492021C3, $\beta_{2} t u b-J T 04 D 144-2021 \mathrm{C} 5, \beta_{2} t u b-2021 \mathrm{D} 96-\mathrm{R} 9 \mathrm{C} 1, \beta_{2} t u b-2021 \mathrm{D} 96-\mathrm{JT} 04 \mathrm{C} 3, \beta_{2} t u b-\mathrm{R} 9 \mathrm{D} 49-\mathrm{R} 9 \mathrm{C} 1$, and $\beta_{2} t u b-\mathrm{JT} 04 \mathrm{D} 144-\mathrm{JT} 04 \mathrm{C} 4$, respectively.

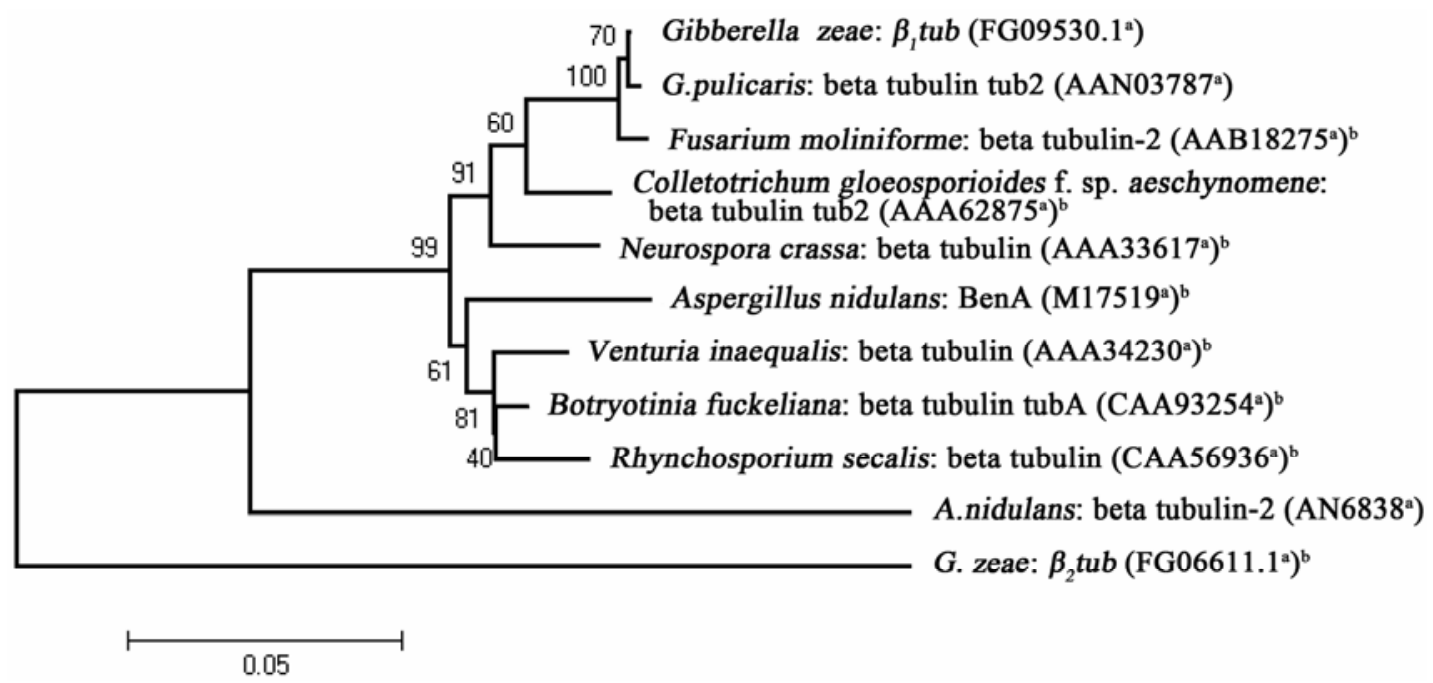

Fig. 5. Phylogenetic relationship of $\beta$-tubulin in Gibberella zeae and other plant-pathogenic fungi based on deduced amino acid sequences. Bootstrap values $(n=$ $1,000)$ are shown at the branch points. 
bendazim susceptibility to MDPC and DFC. (iv) The substitution of Glu198Lys in M. fructicola (17), P. expansum (17), T. acuformis (1), and T. yalhundae (1) confers moderate resistance to carbendazim susceptibility to MDPC as well as insusceptibility to DFC. (v) The substitution of Glu198Val in P. expansum (17) confers high resistance to carbendazim susceptibility to MDPC as well as insusceptibility to DFC. Second, the benzimidazole resistance in the other pathogens was conferred by mutations in a $\beta$ tubulin gene that has high identity to the $\beta_{l} t u b$ gene of $G$. zeae, whereas the $\mathrm{MBC}$ resistance in $G$. zeae reported in the current article was conferred by mutation in the $\beta_{2} t u b$. This may result in not only the much lower resistance factor (mean $\mathrm{EC}_{50}$ of resistant population/mean $\mathrm{EC}_{50}$ of sensitive population) of G. zeae compared with B. cinerea (13), Sclerotinia homoeocarpa (12), Venturia inaequalis (17), and others (21) but also the similar $\mathrm{EC}_{50}$ values and the different $\mathrm{MIC}$ values of $\mathrm{MBC}^{\mathrm{MR}}$ and $\mathrm{MBC}^{\mathrm{HR}}$ strains of G. zeae.

Both $\beta_{1} t u b$ and $\beta_{2} t u b$ of $G$. zeae are expressed during mycelial growth, which differs from the pattern observed for benA and tubC of A. nidulans (24).

$\beta_{2} t u b$-deletion mutants of $G$. zeae showed supersensitivity to MBC but also reduced growth on MBC-free PDA. This result suggests that $\beta_{1} T u b$ can provide what is necessary for growth without $\beta_{2} T u b$. The $\beta_{1} t u b$-deletion mutants of $G$. zeae, however, grew normally on MBC-free PDA (data not shown). Thus, this difference of $\beta_{2} t u b$ - and $\beta_{1} t u b$-deletion mutants implies that the functions of $\beta_{1}$ Tub and $\beta_{2}$ Tub of $G$. zeae differ in mycelial growth.

\section{ACKNOWLEDGMENTS}

This research was sponsored by the Ministry of Science and Technology of China (973 programe 2006CB101907 and 863 programe 2008AA10Z414) and the National Nature Science Foundation of China (no. 30671384, 30971891, and 30671048).

\section{LITERATURE CITED}

1. Albertini, C., Gredt, M., and Leroux, P. 1999. Mutations of the b-tubulin gene associated with different phenotypes of benzimidazole resistance in the cereal eye spot fungi Tapesia yallundae and Tapesia acutormis. Pestic. Biochem. Physiol. 64:17-23.

2. Altschul, S. F., Madden, T. L., Shaffer, A. A., Zhang, Z., Miller, W., and Lipman, D. J. 1997. Gapped BLAST and PSI-BLAST: a new generation of protein database search programs. Nucleic Acids Res. 25:3389-3402.

3. Atanassov, Z., Nakamura, C., Mori, N., Kaneda, C., Kato, H., Jin, Y. Z., Yoshizawa, T., and Murai, K. 1994. Mycotoxin production and pathogenicity of Fusarium species and wheat resistance to Fusarium head blight. Can. J. Bot. 72:161-167.

4. Baraldi, E., Mari, M., Chierici, E., Pondrelli, M., Bertolini, P., and Pratella, G. C. 2003. Studies on thiabendazole resistance of Penicillium expansum of pears, pathogenic fitness and genetic characterization. Plant Pathol. 52:362-370.

5. Bollen, G. J., and Scholten, G. 1971. Acquired resistance to benomyl and some other systemic fungicides in a strain of Botrytis cinerea in cyclamen. Neth. J. Plant Pathol. 77:83-90.

6. Chen, C. J., Li, J., Qi, Z. Q., Wang, J. X. and Zhou, M. G. 2005. Cloning of $\alpha$-tubulin gene from Fusarium graminearum and analyzing its relationship with MBC resistance. Acta Microbiol. Sin. 45:288-291.

7. Chen, C. J., Wang, J. X., Luo, Q. Q., Yuan, S. K., and Zhou, M. G. 2007. Characterization and fitness of carbendazim-resistant strains of Fusarium graminearum (wheat scab). Pest Manage. Sci. 63:1201-1207.

8. Chen, C. J., Wang, J. X., and Zhou, M. G. 2005. Cloning of $\gamma$-tubulin gene from Fusarium graminearum and analyzing its relationship with carbendazim resistance. Acta Phytopathol. Sin. 35:161-167.

9. Chen, C. J., Zhou, L. B., Bi, Z. W., Luo, Q. Q., Wang, J. X., Li H. X., and Zhou, M. G. 2008. Resistant mechanism of Fusarium graminearum against carbendazim, un-relative to alpha2-tubulin gene. Acta Microbiol. Sin. 48:1356-1361.

10. Correll, J. C., Klittich, C. J. R., and Leslie, J. F. 1987. Nitrate nonutilizing mutants of Fusarium oxysporum and their use in vegetative compatibility tests. Phytopathology 77:1640-1646.

11. Davidse, L. C. 1986. Benzimidazole fungicides: Mechanism of action and biological impact. Annu. Rev. Phytopathol. 24:43-65.
12. Detweiler, A. R., Vargas, J. M., and Danneberger, T. K. 1983. Resistance of Sclerotinia homoeocarpa to iprodione and benomyl. Plant Dis. 67:627630.

13. Faretra, F., and Pollastro, S. 1991. Genetic basis of resistance to benzimidazole and dicarboximide fungicides in Botryotinia fuckeliana and Botrytis cinerea. Mycol. Res. 95:943-951.

14. Hell, T. A. 1999. Bioedit A user-friendly biological sequence alignment editor and analysis program for windows 95/98/NT. Nucleic Acids Symp. Ser. 41:95-98.

15. Kawchuk, L. M., Hutchison, L. J., Verhaeghe, C. A., Lynch, D. R., Bains, P. S., and Holley, J. D. 2002. Isolation of the b-tubulin gene and characterization of thiabendazole resistance in Gibberella pulicaris. Can. J. Plant Pathol. 24:233-238.

16. Koenraadt, H., and Jones, A. L. 1993. Resistance to benomyl conferred by mutations in codon 198 or 200 of the beta-tubulin gene of Neurospora crassa and sensitivity to diethofencarb by codon 198. Phytopathology 83:850-854.

17. Koenraadt, H., Somerville, S. C., and Jones, A. L. 1992. Characterization of mutations in the beta-tubulin gene of benomyl-resistant field strains of Venturia inaequalis and other plant pathogenic fungi. Phytopathology 82:1348-1354.

18. Kumar, S., Tamura, K., and Nei, M. 2004. MEGA3: integrated software for molecular evolutionary genetics analysis and sequence alignment. Brief. Bioinf. 5:150-163.

19. Kwa, M. S. G., Veenstra, J. G., vanDijk, M., and Roos, M. H. 1995. $\beta$ Tubulin genes from the parasitic nematode Haemonchus contortus modulate drug resistance in Caenorhabditis elegans. J. Mol. Biol. 246:500-510.

20. Luck, J. E., and Gillings, M. R. 1995. Rapid identification of benomyl resistant strains of Botrytis cinerea using the polymerase chain reaction. Mycol. Res. 99:1483-1488.

21. Ma, Z., and Michailides, T. J. 2005. Advances in understanding molecular mechanisms of fungicide resistance and molecular detection of resistant genotypes in phytopathogenic fungi. Crop Prot. 24:853-863.

22. Ma, Z., Yoshimura, M., and Michailides, T. J. 2003. Identification and characterization of benzimidazole resistance in Monilinia fructicola from stone fruit orchards in California. Appl. Environ. Microbiol. 69:71457152.

23. Maier, F. J., Malz, S., Losch, A. P., Lacour, T., and Schafer, W. 2005. Development of a highly efficient gene targeting system for Fusarium graminearum using the disruption of a polyketide synthase gene as a visible marker. FEMS Yeast Res. 5:653-662.

24. May, G. S. 1989. The highly divergent $\beta$-tubulins of Aspergillus nidulans are functionally interchangeable. J. Cell Biol. 109:2267-2274.

25. McKay, G. J., and Cooke, L. R. 1997. A PCR-based method to characterize and identify benzimidazole resistance in Helminthosporium solani. FEMS Microbiol. Lett. 152:371-378.

26. Mullins, E. D., Chen, X., Romaine, P., Raina, R., Geiser, D. M., and Kang, S. 2001. Agrobacterium-mediated transformation of Fusarium oxysporum: An efficient tool for insertional mutagenesis and gene transfer. Phytopathology 91:173-180.

27. Park, Y. S., Choi, I. D., Kang, C. M., Ham, M. S., Kim, J. H., Kim, T. H., Yun, S. H., Lee, Y. W., Chang, H. I., Sung, H. C., and Yun, C. W. 2006. Functional identification of high-affinity iron permeases from Fusarium graminearum. Fungal Genet. Biol. 43:273-282.

28. Proctor, R. H., Hohn, T. M., and McCormick, S. P. 1997. Restoration of wild-type virulence to Tri5 disruption mutants of Gibberella zeae via gene reversion and mutant complementation. Microbiology 143:2583-2591.

29. Sanger, F., Nicklens, S., and Coulsen, A. R. 1977. DNA sequencing with chain termination inhibitors. Proc. Natl. Acad. Sci. USA 74:5463-5467.

30. Seip, E. R., Woloshuk, C. P., Payne, G. A., and Curtis, S. E. 1990. Isolation and sequence analysis of a $\beta$-tubulin gene from Aspergillus flavus and its use as a selectable marker. Appl. Environ. Microbiol. 56:3686-3692.

31. Thompson, J. D., Higgins, D. G., and Gibson, T. J. 1994. CLUSTAL W: Improving the sensitivity of progressive multiple sequence alignment through sequence weighting, position-specific gaps penalties and weight matrix choice. Nucleic Acids Res. 22:4673-4680.

32. Wicks, T. 1974. Tolerance of the apple scab fungus to benzimidazole fungicides. Plant Dis. Rep. 58:886-889.

33. Yin, Y., Liu, X., Li, B., and Ma, Z. 2009. Characterization of Sterol demethylation inhibitor-resistant isolates of Fusarium asiaticum and $F$. graminearum collected from wheat in China. Phytopathology 99:487-497.

34. Yu, J. H., Hamari, Z., Han, K. H., Seo, J. A., Yazmid, R. D., and Scazzocchio, C. 2004. Double-joint PCR: A PCR-based molecular tool for gene manipulations in filamentous fungi. Fungal Genet. Biol. 41:973981.

35. Yuan, S. K., and Zhou, M. G. 2005. A major gene for resistance to carbendazim, in field isolates of Gibberella zeae. Can. J. Plant Pathol. 27:58-63. 